\title{
Skrining Talasemia Beta Minor pada Pelajar SMK di Kecamatan
} Ciamis

\author{
Doni Setiawan¹, Atun Farihatun², Ary Nurmalasari ${ }^{3}$ \\ 1,2,3Program Studi Teknologi Laboratorium Medik, Sekolah Tinggi Ilmu Kesehatan Muhammadiyah \\ Ciamis, Jawa Barat \\ donisetiawan@stikesmucis.ac.id ${ }^{1}$, atunfarihatun@stikesmucis.ac.id², \\ arynurmalasari3@stikesmucis.ac.id ${ }^{3}$
}

\author{
ABSTRAK \\ Diajukan 6 Juli 2020 Diperbaiki 27 Agustus 2020 Diterima 28 Agustus 2020
}

Latar Belakang: Frekuensi talasemia beta minor di Indonesia mencapai 6-10\%. Talasemia beta minor bersifat asimtomatik sehingga peran deteksi dini perlu dilakukan untuk mencegah kelahiran talasemia mayor. Pemeriksaan hematologi telah diketahui dan teruji dapat digunakan untuk skrining talasemia beta minor pada populasi beresiko. Meningkatnya penderita talasemia beta mayor di Kabupaten Ciamis dikarenakan belum maksimalnya skrining dilakukan.

Tujuan: Mengetahui frekuensi talasemia beta minor pada pelajar SMK di Kecamatan Ciamis.

Metode: Penelitian ini menggunakan metode deskriptif kuantitatif, dengan teknik cross-sectional, yang telah dilakukan sejak bulan Maret-Juni 2020. Subjek penelitian adalah pelajar SMK di Kecamatan Ciamis. Parameter pemeriksaan yang digunakan untuk skrining talasemia beta minor adalah MCV, Indeks Mentzer, Indeks RDW, dan OTOFT.

Hasil: Dari seluruh pelajar yang mengisi kuesioner sebanyak 238 pelajar, hanya 60 pelajar yang bersedia dan memenuhi kriteria penelitian. Hasil pemeriksaan parameter skrining talasemia beta minor didapatkan $5(8,3 \%)$ pelajar MCV $<80 \mathrm{fL}, 3(5 \%)$ pelajar Indeks Mentzer $<13$, Indeks RDW $<220$ $6(10 \%)$ pelajar dan $9(15 \%)$ pelajar dengan OTOFT positif.

Kesimpulan: Pada penelitian ini ditemukan $3(5 \%)$ pelajar sebagai talasemia beta minor.

Kata kunci: talasemia; skrining pembawa sifat; pemeriksaan hematologi; indeks eritrosit

\section{ABSTRACT}

Background: The frequency of beta thalassemia trait in Indonesia reaches 6-10\%. Beta thalassemia trait is asymptomatic so that the role of early detection needs to be done to prevent the birth of thalassemia major. Beta thalassemia trait screening with haematological examination has been known and tested to determine thalassemia suspects. The increase in patients with beta thalassemia trait in Ciamis is because screening has not been maximized.

Objective: The aim of the study is to determine the frequency of beta thalassemia trait in vocational high school students in Ciamis.

Methods: A quantitative descriptive study with cross-sectional data collection had been done during MarchJune 2020. The research subjects were vocational students in Ciamis District. The examination parameters used for screening beta thalassemia trait are MCV, Mentzer Index, RDW Index and OTOFT.

Results: The all students who filled out the questionnaire were 238 students, only 60 students who were willing and met the research criteria. The results of examination of beta thalassemia trait screening parameters found 5 (8.3\%) MCV students <80 fL, 3 (5\%) Mentzer Index students $<13$, RDW Index $<2206$ (10\%) students and 9 $(15 \%)$ students with OTOFT is positive.

Conclusion: In this study found $3(5 \%)$ students as beta thalassemia trait.

Keywords: thalassaemia; carrier screening; hematological test; red cell indice 
PENDAHULUAN

Talasemia merupakan salah satu penyakit yang disebabkan karena adanya kelainan hemoglobin (hemoglobinopati) (Sumantri et al., 2017). Penyakit ini ditandai dengan berkurangnya atau tidak adanya rantai alfa atau beta globin, dua subunit protein dari molekul hemoglobin (Hb) (Atlanta et al., 2017). Talasemia merupakan jenis anemia kronis, mikrositik, yang terkait dengan kerusakan sintesis $\mathrm{Hb}$ dan pengurangan umur eritrosit. Penyakit ini terdistribusi di Mediterania, Timur Tengah, Asia Selatan dan Asia Tenggara (Pour et al., 2015).

Berdasarkan data World Bank, bahwa $7 \%$ dari populasi dunia merupakan talasemia minor atau pembawa sifat talasemia. Asia Tenggara menyumbang sekitar $50 \%$ pembawa talasemia dunia. Frekuensi pembawa talasemia beta di Indonesia sekitar 6-10\% (Alyumnah et al., 2016). Provinsi Jawa Barat merupakan wilayah dengan prevalensi talasemia tinggi di Indonesia (Qazi et al., 2014). Hasil penelitian sebelumnya yang dilakukan oleh Aliyumnah, Ghozali dan Dalimoenthe pada tahun 2016 ditemukan talasemia beta minor pada siswa-siswi SMA di Kecamatan Jatinangor yaitu 12 $(9,3 \%) \quad$ orang. Kabupaten Ciamis merupakan salah satu Kabupaten di Jawa Barat dimana banyak ditemukan penderita talasemia.

Berdasarkan data dari Rumah Sakit Umum Daerah Ciamis (RSUD) dan POPTI (Persatuan Orang tua Penderita Talasemia Indonesia) Kabupaten Ciamis, penderita talasemia beta mayor di Kabupaten Ciamis meningkat lebih dari $100 \%$ dalam kurun waktu lima tahun terakhir, pada tahun 2019 menjadi 184 pasien (RSUD Ciamis, 2019). Hal ini disebabkan karena belum maksimalnya deteksi dini talasemia di Kabupaten Ciamis (Rahayu et al., 2016).

Talasemia beta minor merupakan bentuk heterozigot, yaitu adanya satu gen normal masih memungkinkan sintesis rantai beta globin, sehingga penderita umumnya secara klinis asimtomatik. Akan menjadi masalah apabila sesama talasemia minor menikah, dimana kemungkinan 25\% anaknya menderita talasemia mayor. Gen talasemia pada talasemia minor akan tetap ada di sepanjang hidupnya, tetapi tidak memerlukan transfusi darah (Bain, 2014; Galanello \& Origa, 2010).

Sebagai upaya untuk mencegah lahirnya penderita talasemia mayor yang berasal dari kedua orang tua dengan talasemia minor, maka penting dilakukannya skrining dan edukasi pada pembawa gen talasemia (Maharani \& Astuti, 2014). Hal tersebut dapat dilakukan dengan pemeriksaan hematologi sederhana seperti pemeriksaan $\mathrm{Hb}$, jumlah sel eritrosit (Red Blood Cell Count/RBC), Mean Corpuscular Volume (MCV), Indeks Mentzer, Indeks RDW dan OTOFT (One Tube Osmotic Fragility Test) untuk mengetahui dan menguji penderita talasemia (Qazi et al., 2014; Salim et al., 2018).

Skrining talasemia pada pelajar SMK sangat efektif dilakukan untuk menekan kejadian talasemia baru. Pelajar SMK lebih mudah dijaring melalui edukasi, karena saat usia tersebut individu bisa dikatakan sudah memiliki pemikiran yang mandiri dan sudah siap menikah, kegiatan edukasi bermanfaat untuk memutus rantai talasemia di Kecamatan Ciamis. Tujuan penelitian ini untuk mengetahui frekuensi talasemia beta minor pada pelajar SMK di Kecamatan Ciamis.

\section{METODE}

Desain penelitian yang digunakan dalam penelitian ini adalah penelitian deskriptif kuantitatif dengan teknik crosssectional. Populasi dalam penelitian ini adalah seluruh pelajar dari delapan SMK di Kecamatan Ciamis yang teregister pada tahun akademik 2019/2020, dengan besar populasi 4.986 subjek. Pengambilan sampel dilakukan sesuai dengan kriteria. Kriteria inklusi pelajar kelas 10, 11 atau 12, 
belum diketahui sebagai penyandang talasemia minor dan bersedia mengikuti penelitian secara tertulis atau informed consent. Kriteria eksklusi yaitu penderita talasemia dan spesimen darah lisis.

Penelitian dilakukan pada bulan Maret sampai dengan Juni 2020. Penelitian dimulai dengan tahapan pengisian kuesioner dan penyampaian informasi talasemia melalui pembagian leaflet informasi talasemia, dengan menggunakan google form. Sebanyak 238 pelajar yang mengisi kuisioner dan 60 pelajar termasuk dalam kriteria inklusi dan bersedia mengikuti penelitian.

Pengambilan darah dari subjek penelitian adalah darah EDTA (Ethylenediaminetetraacetic acid) sebanyak 3,0 mL, oleh tenaga ATLM (Ahli Teknologi Laboratorium Medik) yang terlatih sesuai Standar Operasional Prosedur yang telah ditetapkan. Pemeriksaan dilakukan di Laboratorium Klinik Wilujeng Imbanagara, Ciamis, Jawa Barat. Pemeriksaan hematologi $(\mathrm{Hb}$, jumlah eritrosit, Hematokrit, $\mathrm{MCV}, \mathrm{MCH}, \mathrm{MCHC}$, dan RDW) menggunakan hematology analyzer (DIRUI BCC-3000B, DIRUI Industrial, China). MCV merupakan pengukuraan ukuran atau volume ratarata eritrosit, dan telah lama menjadi indeks eritrosit yang berguna untuk mendiagnosis anemia defisiensi besi, dan juga merupakan tanda adanya gangguan disfungsi sumsum tulang (Hsieh et al., 2017). Nilai MCV didapatkan dari hasil bagi hematokrit dengan jumlah sel eritrosit. Nilai batas MCV yang digunakan untuk menunjukkan talasemia beta minor adalah $<80 \mathrm{fL}$ (Brancaleoni et al., 2016).

Indeks Mentzer dihitung dengan menggunakan rumus MCV/RBC. Indeks mentzer dapat digunakan untuk mendiagnosa talasemia beta minor, dimana nilai Indeks Mentzer kurang dari 13 terdiagnosa sebagai talasemia beta minor dan lebih dari 13 merupakan anemia defisiensi besi. Indeks Mentzer memiliki nilai sensitivitas dan spesifisitas tertinggi sehingga dapat digunakan sebagai teknik skrining untuk mendiagnosis talasemia beta minor (Siswandari et al., 2019).

Indeks RDW (Red blood cell distribution width) merupakan indeks yang menggambarkan variasi ukuran (anisositosis) dan bentuk (poikilositosis) sel darah merah. RDW digunakan untuk mendiagnosis penyebab anemia $(\mathrm{Hu}$, 2016). Indeks RDW diperoleh dengan nilai MCV dikali dengan hasil bagi dari jumlah eritrosit (juta per mikroliter) dengan RDW. Indeks RDW merupakan parameter yang andal dan bermanfaat untuk skrining awal anemia hipokromik mikrositik dan digunakan untuk membedakan anemia defisiensi besi dengan talasemia beta minor (Jameel et al., 2017). Nilai indeks RDW lebih dari 220 menunjukkan anemia defisiensi besi, sedangkan kurang dari 220 menunjukkan talasemia beta minor (Rahim \& Keikhaei, 2009).

Pemeriksaan fragilitas osmotik sangat efektif dalam membedakan talasemia beta minor dengan anemia defisiensi besi, hasil positif OTOFT menunjukkan talasemia beta minor. OTOFT dapat mendeteksi 96$100 \%$ talasemia beta minor (Sumera et al., 2012). Pemeriksaan OTOFT dilakukan dengan $0,02 \mathrm{~mL}(20 \mu \mathrm{L})$ darah vena dimasukan dalam tabung reaksi berisi 4,0 $\mathrm{mL} \mathrm{NaCl}$ 0,36\%, setelah itu tabung ditutup. Setelah 5 menit tabung di kocok, dengan membolak balikan selama lima kali. Selanjutnya diamati secara visual. Interpretasi hasil, jika keruh berarti positif (hemolisis tidak sempurna) dan jika jernih berarti negatif (hemolisis sempurna) (Sumera et al., 2012). Selanjutnya, penentuan subjek sebagai tersangka talasemia beta minor dengan memenuhi kriteria yaitu MCV $<80 \mathrm{fL}$, Indeks Mentzer < 13, Indeks RDW < 220 dan OTOFT positif (Alyumnah et al., 2016; Ayu NP, 2015).

Data hasil pemeriksaan dianalisis 
Skrining Talasemia Beta Minor pada Pelajar SMK di Kecamatan...

dengan menggunakan program pengolahan data SPSS. Penelitian ini telah mendapat persetujuan dari Komite Etik Penelitian Kesehatan Sekolah Tinggi Ilmu Kesehatan Bakti Tunas Husada Tasikmalaya (No:015/kepk-bth/V/2020).

\section{HASIL DAN PEMBAHASAN}

Dari total 4.986 pelajar dari delapan SMK di Kecamatan Ciamis, sebanyak 238 $(4,7 \%)$ pelajar berpartisipasi dalam penelitian dan mengisi google form. Karakteristik populasi penelitian ditunjukkan pada Tabel 1. Sebanyak $35,6 \%$ populasi dari penelitian memiliki pengetahuan terkait talasemia, dan hanya $3,4 \%$ yang pernah mengikuti penyuluhan atau seminar talasemia. Hal ini menunjukkan rendahnya pengetahuan dan kurangnya penyuluhan talasemia pada pelajar SMK di Kecamatan Ciamis.

Edukasi dan penyuluhan talasemia pada pelajar di Kecamatan Ciamis diperlukan karena edukasi dan kampanye program preventif talasemia penting dilakukan untuk menyukseskan program pencegahan talasemia. Sekolah sebagai fasilitas penyuluhan merupakan tempat yang efektif karena institusi pendidikan seperti SMK merupakan tempat dilaksanakannya proses pembelajaran. Beberapa hasil penelitian membuktikan bahwa masyarakat yang teredukasi dengan baik akan meningkatkan kesadaran masyarakat tentang bahaya talasemia. Pengetahuan talasemia dan skrining talasemia pada orang muda yang belum menikah terbukti menurunkan kelahiran bayi dengan thalassemia (Ayu NP, 2015). Sebanyak $2,1 \%$ populasi merupakan anggota keluarga penderita talasemia dan 2,9\% merupakan penderita talasemia. Hal ini menunjukkan bahwa banyaknya penderita talasemia di Ciamis sesuai data POPTI Kabupaten Ciamis tahun 2019 terdapat 184 penderita talasemia beta mayor (RSUD Ciamis, 2019).
Tabel 1. Karakteristik Populasi Pelajar SMK di Kecamatan Ciamis

Usia (tahun)

\section{Karakteristik}

\begin{tabular}{ccc}
$\%$ & $\mathbf{n}$ & $\mathbf{M e}$ \\
\hline & & 17
\end{tabular}

Jenis Kelamin

Laki-laki 132

Perempuan 106

Memiliki pengetahuan terkait 35,6 talasemia

Pernah mengikuti

penyuluhan/seminar

talasemia

Anggota keluarga penderita

talasemia mayor

Penderita talasemia mayor

17

Sampel teriklusi

60

Sampeltereksklusi

178

$\mathrm{n}$ : jumlah; Me : Median

Sebanyak 60 (25,2\%) pelajar yang mengisi google form dan masuk dalam kriteria melakukan skrining talasemia beta minor. Karakteristik sampel ditunjukkan pada Tabel 2.

Tabel 2. Hasil Pemeriksaan Status Eritrosit Pelajar SMK di Kecamatan Ciamis

\begin{tabular}{|c|c|c|c|}
\hline Parameter & $\begin{array}{l}\text { Mean } \\
( \pm \text { SD })\end{array}$ & Me & $\mathbf{n}$ \\
\hline Hemoglobin (g/dL) & $14,2 \pm 1,9$ & & \\
\hline Hematokrit (\%) & $43,7 \pm 5,5$ & & \\
\hline Jumlah Eritrosit $\left(10^{\wedge} 6 / \mu \mathrm{L}\right)$ & & 4,96 & \\
\hline $\mathrm{MCV}(\mathrm{fL})$ & & 90,5 & \\
\hline $\mathrm{MCH}(\mathrm{pg})$ & & 29,45 & \\
\hline $\mathrm{MCHC}(\mathrm{g} / \mathrm{dL})$ & & 32,45 & \\
\hline RDW (\%) & & 14,00 & \\
\hline Indeks Mentzer & & 18,41 & \\
\hline Indeks RDW & & 255,28 & \\
\hline \multicolumn{4}{|l|}{ OTOFT (n) } \\
\hline Positif & & & 9 \\
\hline Negatif & & & 51 \\
\hline
\end{tabular}

$\mathrm{n}$ : jumlah; Me : Median

Berdasarkan hasil pemeriksaan hematologi seperti pada tabel 2, kadar $\mathrm{Hb}$ pada pelajar cenderung memiliki nilai sesuai nilai rujukan (perempuan 12-15 g/ dL dan laki-laki 13-17 g/dL) atau tidak mengalami anemia (Goodnough \& Schrier, 2014). Hal ini karena orang dengan talasemia minor selalu memiliki nilai $\mathrm{Hb}$ sesuai dengan nilai rujukan atau anemia ringan (Nuinoon et al., 2014). 
Manifestasi klinis talasemia minor biasanya ringan dan signifikan, tidak selalu diikuti dengan anemia. Umumnya memiliki kualitas hidup yang baik dan tidak memerlukan perawatan khusus (Roth et al., 2018). Orang dengan talasemia beta minor terlihat seperti orang normal pada umumnya sebab mereka tidak merasa sakit (asimptomatik).

Permasalahan talasemia akan muncul jika talasemia menikah dengan sesama talasemia minor sehingga 25\% dari keturunannya akan mengalami talasemia mayor, 50\% kemungkinan anaknya menderita talasemia minor dan hanya $25 \%$ kemungkinan anaknya mempunyai darah normal (Sarwani et al., 2012). Hal inilah yang menyebabkan talasemia beta minor sulit untuk dideteksi dan karena itu skrining talasemia menjadi sangat penting dilakukan.

Skrining terhadap talasemia beta minor pada penelitian ini menggunakan parameter pemeriksaan hematologi rutin yaitu kadar $\mathrm{Hb}$, jumlah eritrosit, $\mathrm{MCV}$, Indeks Mentzer, Indeks RDW dan OTOFT seperti yang telah dilakukan penelitipeneliti sebelumnya (Qazi et al., 2014; Salim et al., 2018).

Tabel 3. Parameter Skrining Talasemia Beta Minor

\begin{tabular}{lcc}
\hline \multicolumn{1}{c}{ Parameter } & n & $\mathbf{\%}$ \\
\hline $\mathrm{MCV}<80 \mathrm{fL}$ & 5 & 8,3 \\
Indeks Mentzer $<13$ & 3 & 5 \\
Indeks RDW $<220$ & 6 & 10 \\
Positif OTOFT & 9 & 15 \\
\hline
\end{tabular}

$\mathrm{n}$ : jumlah

Tabel 3 menunjukkan terdapat lima pelajar $(8,3 \%)$ yang memiliki nilai dibawah $\mathrm{MCV}<80 \mathrm{fL}$, dimana $\mathrm{MCV}$ merupakan parameter hematologi yang menunjukan ukuran rata-rata sel darah merah yang menyebabkan anemia mikrositik, berkurang pada anemia defisiensi besi dan talasemia beta minor (Noor et al., 2020) Pada penelitian ini, nilai MCV kurang dari $80 \mathrm{fL}$ digunakan sebagai nilai cut-off untuk mencurigai responden sebagai talasemia beta minor, karena MCV merupakan parameter pemeriksaan Indeks eritrosit yang direkomendasikan untuk skrining (Tari et al., 2018). Sensitivitas dan spesifisitas cut-off $\mathrm{MCV}$ kurang dari $80 \mathrm{fL}$ adalah $81,3 \%$ dan 95,8\% (Hapsari \& Rujito, 2015).

MCV tidak dapat membedakan talasemia beta minor dan anemia defisiensi besi, maka untuk selanjutnya harus dilakukan pengujian definitif meliputi deteksi kuantitatif $\mathrm{HbA} 2$ dan analisis mutasi DNA. Meskipun akurat, tes tersebut terlalu mahal dan memakan waktu untuk skrining massal. Berbagai formula perhitungan telah diusulkan sesuai dengan Indeks eritrosit, seperti Indeks Mentzer dan Indeks RDW.

Formula tersebut telah diuji dengan nilai cut-off yang berbeda dan dapat digunakan untuk skrining talasemia beta minor, serta dapat digunakan untuk membedakan talasemia beta minor dan anemia defisiensi besi (Miri-Moghaddam \& Sargolzaie, 2014). Maka dalam penelitian ini menggunakan Indeks Mentzer dan Indeks RDW, dimana nilai cut-off Indeks Mentzer <13, memiliki sensitivitas 98,7 $\%$, spesifisitas 82,3\%, Positive Predictive Value (PPV) 82,3\%, dan Negative Predictive Value (NPV) 98,2\%. Untuk cut-off Indeks RDW <220, memiliki sensitivitas $83,1 \%$, spesifisitas 76,4\%, PPV 80\% dan NPV $80 \%$ (Vehapoglu et al., 2014).

Hasil pada tabel 3 menunjukkan pelajar yang memiliki nilai Indeks Mentzer $<13$ dan Indeks RDW <220, masingmasing adalah 3 orang (5\%) dan 6 orang pelajar $(10 \%)$. Jumlah pelajar yang teridentifikasi talasemia beta minor oleh Indeks RDW lebih besar dibandingkan dengan Indeks Mentzer, hal ini karena nilai spesifisitas, PPV dan NPV Indeks Mentzer lebih baik dibandingkan dengan Indeks RDW.

Menurut hasil pemeriksaan OTOFT pada tabel 3, jumlah pelajar yang positif sebanyak 9 orang (15\%). OTOFT merupakan metode sederhana dan murah, 
yang digunakan untuk deteksi eritrosit mikrositik. Fragilitas osmotik eritrosit dipengaruhi ukuran dan bentuknya dimana semakin kecil selnya, semakin resisten (Penman et al., 2015). Kelainan eritrosit berupa leptosit dapat ditemukan pada kasus yang memiliki MCV rendah dibandingkan dengan nilai rujukan dan lebih resisten terhadap lisis, seperti pada talasemia beta minor. Pemeriksaan ini diperlukan untuk menilai kemampuan membran eritrosit (Walski et al., 2014). Namun, pada penelitian ini pemeriksaan OTOFT menunjukkan keterbatasan sebagai tes skrining untuk talasemia beta minor, hal ini telah dilaporkan dalam penelitian-penelitian sebelumnya. Hal ini karena spesifisitas yang buruk pada populasi dengan anemia defisiensi besi.

Pada penelitian sebelumnya, telah menunjukkan keberhasilan OTOFT dapat digunakan sebagai penyaringan awal yang efektif untuk mengidentifikasi talasemia beta minor (Patel et al., 2015). Rendahnya spesifistas dan PPV pemeriksaan OTOFT menyebabkan lebih banyak pelajar yang terjaring sebagai tersangka talasemia beta minor. Dimana sensitivitas pemeriksaan ini adalah 92,2\%, spesifisitas 62,6\%, PPV 60,5\% dan NPV 89,0\% (Patel et al., 2015).

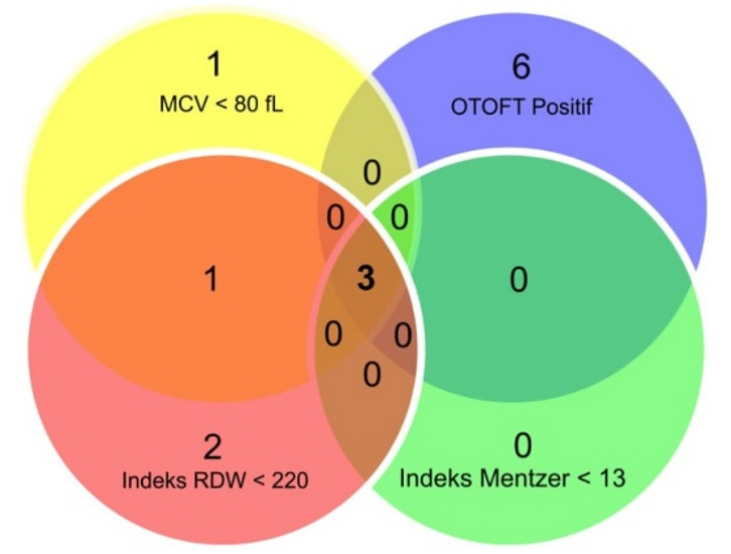

Gambar 1. Irisan Parameter Skrining Talasemia Beta Minor

Dari Gambar 1 dapat dilihat bahwa dari penelitian ini terdapat 3 pelajar $(5 \%)$ merupakan penderita talasemia beta minor. Hasil dari penelitian ini menunjang penelitian epidemiologi di
Indonesia bahwa frekuensi gen Talasemia beta berkisar 3-8\% (Rejeki et al., 2014). Penelitian ini memiliki keterbatasan yaitu tidak dilakukannya diagnosis pasti dengan pemeriksaan gold standard, karena penelitian ini merupakan skrining talasemia beta minor. Pemeriksaan gold standard untuk diagnosis talasemia beta minor adalah elektroforesis atau analisis $\mathrm{Hb}$ dengan HPLC. Namun, metode pemeriksaan hematologi otomatis yang andal dan murah secara signifikan dapat mendeteksi talasemia beta minor pada populasi berisiko. Subjek penderita tersebut dapat dirujuk untuk konseling genetik lebih lanjut dan melakukan pemeriksaan gold standard lebih lanjut untuk mengkonfirmasi diagnosis (Roth et al., 2018).

\section{KESIMPULAN}

Frekuensi talasemia beta minor pada pelajar SMK di Kecamatan Ciamis pada penelitian ini adalah tiga pelajar (5\%) yang artinya lima dari seratus pelajar SMK di kecamatan Ciamis membawa sifat talasemia. Talasemia beta minor bersifat asimtomatik dimana para pelajar tidak pernah mengetahui bahwa dirinya adalah pembawa sifat talasemia sebelum dilakukan pemeriksaan. Perlunya peningkatan kesadaran masyarakat untuk memeriksakan diri, melalui edukasi atau penyuluhan.

\section{UCAPAN TERIMA KASIH}

Peneliti mengucapkan terimakasih kepada pihak yang telah ikut berkontribusi dan mendukung penelitian ini diantaranya STIKes Muhmmadiyah Ciamis, serta Kementerian Riset dan Teknologi/Badan Riset dan Inovasi Nasional atas bantuan dana untuk melaksanakan penelitian ini melalui Hibah Penelitian Dosen Pemula (PDP) Tahun 2020. 
DAFTAR PUSTAKA

Alyumnah, P., Ghozali, M., \& Dalimoenthe, N. Z. (2016). Suspected Beta Thalassemia Minor Screening in Jatinangor High School Students. Jurnal Sistem Kesehatan, 1(3), 133-138. http://jurnal.unpad.ac.id/jsk_ikm/ article/download/10358/4731

Atlanta, H., Drive, U., \& Quinn, C. T. (2017). Gene and Cell Therapies for Beta-Globinopathies. In P. Malik \& J. Tisdale (Eds.), Adv Exp Med Biol (Vol. 1013). Springer New York. https:// doi.org/10.1007/978-1-4939-7299-9

Ayu NP, R. (2015). Indeks RDW dan Mentzer sebagai Uji Skrining Diagnosis Thalassemia. Majority, 4(7), 7-12. https:// juke.kedokteran.unila.ac.id/index.php/ majority/article/view/1440

Bain, B. J. (2014). Hematologi: Kurikulum Inti (A. S. Y.Joko Suyono, Ferdy Sandra (ed.)). EGC.

Brancaleoni, V., Di Pierro, E., Motta, I., \& Cappellini, M. D. (2016). Laboratory diagnosis of thalassemia. International Journal of Laboratory Hematology, 38, 3240. https://doi.org/10.1111/ijlh.12527

Galanello, R., \& Origa, R. (2010). Betathalassemia. Orphanet Journal of Rare Diseases, 5(1), 11. https://doi.org/ 10.1186/1750-1172-5-11

Goodnough, L. T., \& Schrier, S. L. (2014). Evaluation and management of anemia in the elderly. American Journal of Hematology, 89(1), 88-96. https://doi.org/10.1002/ajh.23598

Hapsari, A. T., \& Rujito, L. (2015). Uji Diagnostik Indeks Darah dan Identifikasi Molekuler Karier Talasemia $\beta$ pada Pendonor Darah di Banyumas. Jurnal Kedokteran Brawijaya, 28(3), 233-237. https:// doi.org/10.21776/ub.jkb.2015.028.03.13

Hsieh, Y. P., Chang, C. C., Kor, C. T., Yang, Y., Wen, Y. K., \& Chiu, P. F. (2017). Mean corpuscular volume and mortality in patients with CKD. Clinical Journal of the American Society of Nephrology, 12(2), 237-244. https:// doi.org/10.2215/CJN.00970116

$\mathrm{Hu}$, Z. (2016). Red blood cell distribution width: a promising index for estimating activity of autoimmune disease. Journal of Laboratory and Precision Medicine, 1(4), 4-4. https:// doi.org/10.21037/jlpm.2016.10.02

Jameel, T., Baig, M., Ahmed, I., Hussain, M. B., \& Alkhamaly, M. bin D. (2017). Differentiation of beta thalassemia trait from iron deficiency anemia by hematological indices. Pakistan Journal of Medical Sciences, 33(3), 665-669. https://doi.org/10.12669/pjms. 333.12098

Maharani, E. A., \& Astuti, D. (2014). Penghitungan Indeks Formula Eritrosit Pada Uji Saring Thalasemia Minor. Jurnal Ilmu Dan Teknologi Kesehatan, 2(1), 53-59. http:// ejurnal.poltekkesjakarta3.ac.id/ index.php/jitek/article/download/ 124/92

Miri-Moghaddam, E., \& Sargolzaie, N. (2014). Cut off determination of discrimination indices in differential diagnosis between iron deficiency anemia and $\beta$ - thalassemia minor. International Journal of HematologyOncology and Stem Cell Research, 8(2), 27-32.

Noor, F. A., Sultana, N., Bhuyan, G. S., Islam, T., Hossain, M., Shekhar, H. U., Qadri, F., Qadri, S. S., \& Mannoor, K. (2020). Nationwide carrier detection and molecular characterization of $\beta$ -thalassemia and hemoglobin $\mathrm{E}$ variants in Bangladeshi population. Orphanet Journal of Rare Diseases, 15(15), 1-12. https://doi.org/10.1186/ s13023-020-1294-z

Nuinoon, M., Kruachan, K., Sengking, W., Horpet, D., \& Sungyuan, U. (2014). Thalassemia and Hemoglobin $\mathrm{E}$ in Southern Thai Blood Donors. Advances in Hematology, 2014, 1-6. https://doi.org/10.1155/2014/932306

Patel, P., Sarda, N., Arora, R., \& Gaikwad, 
H. (2015). Comparative evaluation of NESTROFT and RDW as screening tests for beta thalassemia trait in pregnancy. International Journal of Reproduction, Contraception, Obstetrics and Gynecology, 4(2), 424. https:// doi.org/10.5455/2320-

1770.ijrcog20150427

Penman, B. S., Gupta, S., \& Weatherall, D. J. (2015). Epistasis and the sensitivity of phenotypic screens for beta thalassaemia. British Journal of Haematology, 169(1), 117-128. https:// doi.org/10.1111/bjh.13241

Pour, M. N., Hagh, M. F., Akbari, A. A. M., Feyzi, A. A. H. P., \& Malaki, M. (2015). Genetic Variation Impacts in Patients with Major Beta-Thalassemia. Iranian Journal of Public Health, 44(5), 722-723. https:// www.ncbi.nlm.nih.gov/pmc/articles/ PMC4537638/

Qazi, R. A., Shams, R., Hassan, H., \& Asif, N. (2014). Screening for Beta Thalassemia Trait. Journal of Rawalpindi Medical College, 18(1), 158160. https://pdfs.semanticscholar.org/ b18d/

dfcf8b46b38402fbd3c769c7114b9bb3f8 f9.pdf

Rahayu, Y., Mulyadi, E., \& Waluyo, J. (2016). Family Support in Compliance Therapy in Patients with Thalassemia in Ciamis District Hospital in 2015. Mutiara Medika, 16(2), 52-56. https:// journal.umy.ac.id/index.php/mm/ article/download/4451/3515

Rahim, F., \& Keikhaei, B. (2009). Better differential diagnosis of iron deficiency anemia from betathalassemia trait. Turkish Journal of Hematology, 26(3), 138-145. http:// www.journalagent.com/tjh/pdfs/

TJH_26_3_138_145.pdf

Rejeki, D. S. S., Pradani, P., Nurhayati, N., \& Supriyanto, S. (2014). Model Prediksi Kebutuhan Darah untuk Penderita Talasemia Mayor. Kesmas: National Public Health Journal, 8(7),
295.

https://doi.org/10.21109/ kesmas.v0i0.368

Roth, I. L., Lachover, B., Koren, G., Levin, C., Zalman, L., \& Koren, A. (2018). Detection of $\beta$-Thalassemia Carriers by Red Cell Parameters Obtained from Automatic Counters using Mathematical Formulas. Mediterranean Journal of Hematology and Infectious Diseases, 10(December 2017), 1-10.

RSUD Ciamis. (2019). Data Kunjungan pasien Thalassemia Tahun 2018-2019.

Salim, Y., Sukartini, N., \& Setiawati, A. (2018). Erythrocyte Indices To Differentiate Iron Deficiency Anemia From B Trait Thalassemia (Indeks Eritrosit untuk Membedakan Anemia Defisiensi Besi dengan Thalassemia $\beta$ Trait). Indonesian Journal of Clinical Pathology and Medical Laboratory, 23(1), 50. https://doi.org/10.24293/ ijcpml.v23i1.1184

Sarwani, D., Rejeki, S., Pradani, P., Nurhayati, N., Kedokteran, F., Kesehatan, I., Jenderal, U., \& Sains, F. (2012). Model Prediksi Kebutuhan Darah untuk Penderita Talasemia Mayor Blood Need Prediction Model for Mayor Thalassemia Patients. Jurnal Kesehatan Masyarakat Nasional Vol., 8(7), 295-300.

Siswandari, W., Rujito, L., Indriani, V., \& Djatmiko, W. (2019). Mentzer Index Diagnostic Value in Predicting Thalassemia Diagnosis. IOP Conference Series: Earth and Environmental Science, 255, 012004. https://doi.org/10.1088/17551315/255/1/012004

Sumantri, N. I., Setiawan, D., \& Sazali, A. (2017). Exon globin mutation of $\beta$ thalassemia in Indonesian ethnic groups: A bioinformatics approach. In N. K. \& S. F. Robert Hofstra (Ed.), Advances in Biomolecular Medicine Proceedings of the 4th BIBMC (Bandung International Biomolecular Medicine Conference) 2016 and the 2nd ACMM 


(ASEAN Congress on Medical
Biotechnology and Molecular Biosciences) 2016 (pp. 99-104). CRC Press Taylor \& Francis Grup. https:// doi.org/10.1201/9781315208619-23

Sumera, A., Ahmed, S., Ali, S. A., \& Khanani, R. (2012). Evaluation of NESTROFT as a marker of differentiation between $\beta$ - thalassemia trait \& iron deficiency anemia. International Journal of Collaborative Research on Internal Medicine and Public Health, 4(8), 1560-1566. https:// internalmedicine.imedpub.com/ evaluation-of-nestroft-as-a-marker-ofdifferentiationbetween--thalassemiatrait--iron-deficiency-anemia.php? aid $=6331$

Tari, K., Alikhani, S., Abbaszadehdibavar, M., Kianinodeh, F., Karam, F., \& Atashi, A. (2018). Evaluation of the sensitivity and specificity of $\mathrm{MCH}$ and MCV for screening of Beta thalassemia minor. International Journal of BioMedicine and Public Health, 1(4), 184-187. https://doi.org/ 10.22631/ijbmph.2018.119048.1021

Vehapoglu, A., Ozgurhan, G., Demir, A. D., Uzuner, S., Nursoy, M. A., Turkmen, S., \& Kacan, A. (2014). Hematological indices for differential diagnosis of beta thalassemia trait and iron deficiency anemia. Anemia, 2014, 1-7. https://doi.org/ $10.1155 / 2014 / 576738$

Walski, T., Chludzińska, L., Komorowska, M., \& Witkiewicz, W. (2014). Individual Osmotic Fragility Distribution: A New Parameter for Determination of the Osmotic Properties of Human Red Blood Cells. BioMed Research International, 2014(January 2014), 1-6. https:// doi.org/10.1155/2014/162102 